\title{
At a standstill after a year
}

\section{Peter Pockley looks at Australian science after 12 months of Mr Fraser's government}

$\mathrm{N}^{\mathrm{O}}$ OVEMBER 11, long celebrated in Australia as Remembrance Day to commemorate the end of the First World War, has now been endowed with a second significance. The day was marked in 1976 by large crowds expressing their continued opposition to the manner in which $\mathrm{Mr}$ Malcolm Fraser and his Liberal/Country Party coalition persuaded the GovernorGeneral, Sir John Kerr, to sack the Labor Government of $\mathrm{Mr}$ Gough Whitlam only two hours after Sir John had laid wreaths on the eleventh hour of the eleventh day of the eleventh month of 1975. Mr Fraser pulled this crisis on Australia, and one month later won the election, on the justification that Labor could not manage the economy.

On his first anniversary in office, $\mathrm{Mr}$ Fraser presided over a stagnant economy with his principal target of curbing the $12-14 \%$ inflation as much out of range as it was under Labor, with an unemployment rate of about $5 \%$ that is the highest since the 1930 s and with worse to come as school and university leavers flood the job market in December and January, and with an even worse industrial record than Labor's. Yet his government remains surprisingly popular, a fact which many observers put down to the success with which the release of information and the opportunities for newsmaking debates have been carefully controlled to the point of almost obsessive secrecy. Last weekend's heavy $17 \frac{1}{2} \%$ devaluation of the Australian dollar could dissipate some of that popularity. The Labor Opposition, however, is only just emerging from the shock of its demoralising defeat.

\section{Effect on science}

This is the context within which the first Fraser Budget and its effect on science must be assessed. With the one exception of grants for medical research, the effect on science generally has been to impose at least one year of treading water, and quite possibly several years of struggle to stay afloat. Fraser and his Treasurer, $\mathrm{Mr}$ Philip Lynch, were determined to tackle inflation principally by drastic cuts in public spending, and their scythe cut deeply into the flesh of all public instrumentalities; unfortunately, most were already lean after cuts by Labor in 1975, and the bones are now exposed.

Take CSIRO, for instance. Its Jubilee year of 1976 has been scarred by a
Budget allocation for 1976-77 of \$131 million (1.6 Australian dollars = £1) which does not even cope with inflation since the 1975-76 allocation was $\$ 123$ million. The government claimed the CSIRO's "activities will be held to the same real levels as in 1975-76", a statement greeted with some cynicism by CSIRO administrators as they go about their cheerless task of cutting staff. The foregoing quote from the Budget paper was preceded by confirmation of "an independent external inquiry into the operation of CSIRO". This inquiry is now underway, but as the Budget said, "In the interim CSIRO's activities will be held ...". It's going to be a hard last period for CSIRO Chairman Sir Robert Price (formerly Dr Jerry Price) and for his unnamed successor who should take over in March 1977.

The 19 universities of Australia are the next greatest sponsors of research. Their growth has been held and there are great uncertainties about the future. Through the Universities Commission, the universities will receive $\$ 562$ million for the calendar year 1977, as compared with $\$ 542$ million for 1976 . The Education Minister, Senator John Carrick, has claimed this constitutes a $2 \%$ real growth rate, but no university administrator has publicly agreed: many are trumpeting "hard times ahead". The situation in universities for funding new equipment and replacing old is marginally better than last year, but the real crunch comes in the provision of staff. "Freezing" of establishments and "natural wastage" are the order of the day as universities face unavoidably increasing costs from salary rises as staff grow older on average and are not balanced by equalising intakes of young, cheaper lecturers.

The two principal sources of government money for supporting the research of individuals and small groups, largely in universities, appeared to fare better in the Budget than ever. This was a shrewd, and essentially very chean, way of the government preventing the kind of damaging outrage which greeted Labor's cuts in these funds in the previous year's Budget. In reality, though, the Australian Research Grants Committee (ARGC) received \$9.1 million, a shade higher only than the previous vear. The National Health and Medical Research Council (NH\&MRC) was the only group smiling as it received $\$ 9.1$ million, a significant increase on $\$ 5.2$ million last year; this

\section{Sorry, for copyright reasons some images on this page may not be available online}

\section{Mr Fraser, 12 months on}

was a tribute to the success of the public lobbying by the medical researchers, which was not matched by those in the natural and social sciences and the humanities serviced by ARGC.

Individual researchers in academia showed last year how well they could protest at threats to their personal support, but in fact they are far more dependent on maintenance of the overall funding received by their institutions and that is decidedly unpredictable. This is because the government has replaced the triennium system of forward funding of universities with, in essence, an annual budgetary arrangement masquerading under the description of "rolling triennium". Significantly also, the previous triennial forward commitments for ARGC and NH\&MRC were quietly dropped and only one-year funding substituted.

The Australian Atomic Energy Commission, under its new part-time Chairman, Professor Don George, faces the year with $\$ 21.1$ million, radiated up only $\$ 1.1$ million on last year. The Antarctic Division of the Department of Science has been frozen at $\$ 6$ million. Industrial Research and Development Grants, administered by the Department of Industry and Commerce, have not develoned at all-they have dronped by $\$ 3.9$ million to $\$ 15.4$ million. Labor's Department of the Environment was swallowed into the maw of a raghag denartment called Environment, Housing and Communitv Develonment with the deliberate intent of spending as little federal money on environment nrotection and research as possible. The whole department suffered a shattering $37 \%$ decrease in funds and the environment part of it did not even rate a mention in the main Budget documents. Defence science and technology received $\$ 89$ million (uv $\$ 5$ million) out of a total defence vote of $\$ 2.178$ million, the only trouble being that nobody really knows what this will be spent on.

Science Department come-back

Reports in these columns earlier this 
year chronicled the tribulations of the Department of Science during the first few months of Fraser, when the very continued existence of the Department seemed unlikely. With some good training beneath their skins for survival gained when the Labor Party come to power, the senior staff of the Department knew that if they could survive the first six months of the cost-slashing Liberals they would coast into the period when the new Cabinet aged rapidly as they had to cope with problems of their own making and could no longer blame their predecessors.

This stage has now arrived. But the Department had good reason to be concerned for its future. Its Minister, Senator James Webster, was 25th out of 25 in seniority and his voice was weak in the face of possible Cabinet reshuffles. The Science Task Force of the Royal Commission on Australian Government Administration had strongly recommended dispersal of the Department's operational divisions among other departments, and there was much support for this view among the scientific community. Fraser had put a hatchet man among the public service to search for and destroy "wasteful and extravagant expenditure", and science was one of those on the block. And there were severe tensions between the Canberra head office and some operational divisions.

In the long run, the hatchets proved blunt and the only waste was the cost of the blades and the unpublished report. The Royal Commission did not come out with a specific recommendation on the Department, and the Secretary, Sir Hugh Ennor, walks taller and looks set to see out his full term to retirement next year.

Senior members of the Department are setting out to win friends they've not previously had in the universities, at the same time as the Australian Science and Technology Council (ASTEC), a potential rival to the Department in the high stakes of policy formulation, is working hard on its own survival. The Department's data collection outfit, Project SCORE, has its statistics on national R\&D expenditure and manpower for 1973-74 at press; official, private inquiries into aspects of research organisation are planned.

The Australian preoccupation with organisations, structures and the dreary politics which go with them to the exclusion of concentration on the substance of research has again been amply demonstrated in Fraser's first year. Plus ça change. . .

\section{Reed in the wind}

An agreement by the Ontario government to give a paper company the right to cut timber and build a mill in the largest area of the province ever proposed for such a purpose has caused a storm in the provincial legislature. David Spurgeon reports from Ottawa

THE recent controversial agreement between the province of Ontario and Reed Paper Limited covers an area of almost 19,000 square miles, larger than the entire province of Nova Scotia. Although it is subject to the outcome of environmental impact studies and hearings-which, according to the premier, William Davis, will take $2 \frac{1}{2}$ years and could still leave the province free to refuse the licence-that has not silenced the critics.

Prominent among them are environmentalists and Indian leaders, and they are led by New Democratic Party leader Stephen Lewis. The "memorandum of agreement" between the province and the company was signed just in time for it to be tabled on the first day of the Ontario legislature's autumn sitting on October 26, and was met by a concerted attack from $\mathrm{Mr}$ Lewis. He produced an internal memo from the government's Environment Ministry indicating that some of its own foresters believed the ministry had failed to enforce proper woodcutting practices. The government later said the memo, which warned of a timber shortage by the year 2000, contained only individual foresters' opinions.

The government said the company must submit to a full hearing by the environment board, which heretofore has dealt only with government projects. All interested parties in the area, such as Indian groups, will be heard by the board. Before that, the company must make public its proposals for a comprehensive forest management plan for its mill, and if the project goes ahead the company must pay back to the government the costs of the studies of timber potential in the area. The agreement expires by January 1980 , if the plans are not approved by then.

One of the reasons for the furore is that Reed is the company which owned the chemical plant that was believed to be responsible for mercury discharges into the English-Wabigoon River system, which disrupted life for hundreds of Indians and raised the spectre of Minamata disease among them. The agreement involves some of the same Indians who were previously affected by the mercury poisoning. While those in the area are flatly opposed to the development, which was initiated without consulting them and which would, in the opinion of some, threaten their livelihood, local white residents feel quite differently.

The proposed development would cost about $\$ 400$ million and provide up to 1,200 new jobs. It would bring new economic life to the area, whose residents for many years have suffered the uncertainties involved in living in this isolated region. One community is Red Lake (population 2,300), a departure point for rich sportsmen who fly into the area for hunting and fishing. It is also the central housing point for workers in the largest industry in the area: gold mining.

Mr Davis has pointed out that many of those who oppose the Reed develop- ment have never visited the area and wouldn't know the difference between a balsam and a jack pine. Red Lake Reeve John Goodwillie sees the paper mill as the basis for an economy other than tourism or the vagaries of gold mining. For years the town has seen mines closing and opening, lay-offs and hirings, and market fluctuations. And many agree with him that the mill is a potential boon-not something to be feared. As for the mercury incident, Goodwillie says that as far as he's concerned, "it wasn't Reed that started polluting Dryden, it was a small company and the only thing that Reed did was buy them out and get stuck for cleaning it up."

Ontario's Minister of Natural Resources, Leo Bernier, has in fact been hinting that the company "might just walk away" from the project because of the criticisms. Both Ear Falls and Red Lake councils have passed resolutions supporting the proposed development.

Some see the controversy in a different light. Mr Bernier has admitted, when questioned, that the province is $1 \frac{1}{2}$ years behind in its reforestation programme. A paper prepared by an employee of the Natural Resources Ministry raised the spectre of huge acreages going out of production annually as a result of present management practices. It also accused Reed of uncontrolled cutting of Boreal softwoods and partial cutting of high quality stands of Boreal mixed woods.

Public pressure may now force a much more active scrutiny of the province's dealings in many areas, since for the first time a private project in Ontario will have to meet economic tests and numerous environmental, social and cultural tests, too--all of it in public. 